\title{
EAST AND WEST ON THE FINNISH SCREEN
}

\section{EARLY TRANSNATIONALTELEVISION IN F I N L A N D}

\author{
Mari Pajala \\ Media Studies \\ 20014 University of Turku \\ Finland \\ mari.pajala@utu.fi
}

\begin{abstract}
Research on Finnish television history has so far emphasized Western influences. However, the Finnish television environment was also shaped in many ways by contacts with socialist television cultures. This article analyses the first volume of the television magazine Katso to trace the various transnational relations, which shaped the early Finnish television environment and to discuss the cultural meanings of socialist television in this environment. Nearly every issue of Katso in 1960 discusses television in a transnational context. Transnational themes fall into four categories: (1) learning about television in other countries; (2) the Eurovision and Nordvision networks; (3) watching television across national borders (Swedish and Tallinn television but also television across surprising distances); and (4) visions of world television. Katso's understanding of television emphasizes the literal meaning of television: to see far. The magazine sets no clear limits to what television could do in terms of overcoming physical distance and ideological borders. The magazine avoids overt politics in discussing television from both the West and the East and represents television broadcasting from Tallinn as a potential source of popular television for Finnish audiences.
\end{abstract}

Keywords: Transnational television, Television in Finland, Television magazines, Television in the 1960s

Finnish television history offers a platform to question the dichotomy between East and West in European television history. After the Second World War, Finland pursued political neutrality, striving for a place between the Western and Eastern blocs, even though it also had a close relationship with the neighbouring Soviet Union through an agreement of 'friendship and cooperation'. While this was the official political line, cultural links with the West were probably always more prominent. Research on Finnish television history has emphasised Western, in particular American, influences. ${ }^{1}$ However, contacts with socialist television cultures also coloured the Finnish television environment in many ways: the Finnish Broadcasting Company YLE was a member of both the European Broadcasting Union (EBU) and Organisation Internationale de Radiodiffusion et de Télévision (OIRT); Tallinn television was available on the southern coast; and Finnish television channels broadcasted programmes from socialist countries (e.g. children's

\footnotetext{
1 See for example Jukka Kortti's study on television advertising in the 1960s and Sari Elfving's analysis of the influence of Peyton Place on the Finnish television culture. Jukka Kortti, Modernisaatiomurroksen kaupalliset merkit: 60-luvun suomalainen televisiomainonta ('The commercial signs of modernisation: Finnish television advertising in the 1960s'), Suomalaisen Kirjallisuuden Seura, 2003; Sari Elfving, 'Peyton Placen lähikuvien vaara ja viettelys: Suomalainen lehdistö television katsojuutta määrittelemässä' ('The danger and seduction of close-ups on Peyton Place: The Finnish press defining television spectatorship'), Lähikuva, 16, 3, 2003, 19-36.
} 
programmes, popular music, feature films). ${ }^{2}$ Historical research on Finnish television organisations has begun to address the political tactics of television professionals in the Cold War context. ${ }^{3}$ However, so far there has been little research on the cultural meanings of socialist television in Finland.

This article analyses the first volume (1960) of the television magazine Katso to illustrate the various transnational encounters that shaped the early Finnish television environment and to trace the cultural meanings of socialist television in it. Recent research on transnational television history has challenged the historical narrative that European television, previously structured as a national medium, only acquired significant transnational features in the 1980s with the development of satellite television and commercial services. ${ }^{4}$ In this article I suggest that transnationality is a particularly useful viewpoint for understanding early television cultures, before television became a medium with national reach. According to Cecelia Tichi, the television environment is shaped by interpretative texts on the meanings of television in various fields of discourse. ${ }^{5}$ The article analyses the television magazine Katso as a forum that participated in the construction of the television environment through its discussion of the forms, meanings and experiences of television. Thus, I am not primarily interested here in the political manoeuvres behind transnational television in the Cold War context. Rather, the article proposes that in order to understand the significance of socialist television in Finland, it is necessary to take into consideration not only behind-the-scenes politics, but also the cultural meanings and uses of socialist television. This article suggests that the Finnish television environment formed in contact with both Western and Eastern influences and provides an analysis of how these influences appeared in one context, Katso.

\section{Katso and Early Television in Finland}

The national public service broadcasting company Yleisradio (YLE) held the only license for radio broadcasting in Finland until 1985. However, the first regular television broadcasts were started in 1956 by TES-TV (from 1960 Tesvisio), a private and commercial television station, run by the Finnish Foundation for Technology Promotion (Tekniikan edistämissäätiö TES) with connections to the Technical Institute (Teknillinen korkeakoulu) in Helsinki. YLE began regular television broadcasts the following year under the name Suomen Televisio (STV, Finland's Television). Another commercial channel, Mainos-TV (MTV), was set up by advertisers, advertising agencies and film companies and started renting broadcasting time on YLE's channel the same year. ${ }^{6}$ In 1960 , Finnish television channels could only be viewed in Southern Finland and there were about 92,500 television license holders, 21 per 1000 inhabitants. $^{7}$ Around half of the television license holders lived in the Helsinki area. ${ }^{8}$ Television spread rapidly in the early 1960 s. Already by the end of 1962, television broadcasts were within reach of half of the geographical area of the country and 90 percent of the population. By the end of 1964, only northernmost Lapland remained outside the television coverage area. ${ }^{9}$

\footnotetext{
2 For example in 1960, The Soviet Union was the second most important source of feature films for YLE with nine films, after the USA (24 films). Kertomus Oy. Yleisradio Ab:n toiminnasta vuonna 1960 ('YLE annual report 1960'), YLE, 1961, p. 73.

${ }^{3}$ Heidi Keinonen, 'Early Commercial Television in Finland,' Media History, 18, 2, 2012, 177-189; Raimo Salokangas, Aikansa oloinen: Yleisradion historia 1926-1996 ('Of its time: The history of Yleisradio 1926-1996'), Yleisradio, 1996, pp. 109-113.

4 Andreas Fickers and Catherine Johnson, 'Transnational Television History: A Comparative Approach,' Media History, $16,1,2010,2$.

5 Cecelia Tichi, Electronic Hearth: Creating an American Television Culture, Oxford University Press, 1991 , pp. 3-7.

${ }^{6}$ See 'Suomalaisen television virstanpylväitä' ('Milestones of Finnish television'), in Juhani Wiio, ed., Television viisi vuosikymmentä: Suomalainen televisio ja sen ohjelmat 1950-luvulta digiaikaan ('Five decades of television: Finnish television and its programmes from the 1950s to the digital age'), Suomalaisen kirjallisuuden seura, 2007, pp. 582-583.

7 Kertomus Oy. Yleisradio Ab:n toiminnasta vuonna 1961 ('YLE annual report 1961'), YLE, 1962, p. 23.

8 Kertomus Oy. Yleisradio Ab:n toiminnasta vuonna 1961, YLE, 1962, p. 24

9 Salokangas 1996, p. 123; Kertomus Oy. Yleisradio Ab:n toiminnasta vuonna 1964 ('YLE annual report 1964'), YLE 1965, pp. $20,25$.
} 
In this context, Katso participated in defining the cultural meanings of television and in producing the television audience. ${ }^{10}$ The name of the magazine, the imperative singular form of the verb 'to watch', literally exhorts readers to become viewers of television. Katso was the first television magazine in Finland. ${ }^{11}$ The first issue came out in August 1960 and from the second issue onwards Katso appeared weekly. The magazine carried television and radio listings, programme information and critiques, and articles about television, radio and other topics. In her study on journalistic writing on Finnish television in the 1960s and 1970s Sari Elfving argues that Katso aspired for a dialogic style, offering itself as a 'place of negotiation where television production, viewers and stars' encountered each other. ${ }^{12}$ The search for a dialogic style can already be seen in the early issues of the magazine, where Katso reported on the experiences of both television professionals and viewers.

The first volume of Katso emphasised the transnational qualities of television. In this article, I use the concept 'transnational' in a broad sense to refer to border crossings of various kinds. As historian Patricia Clavin notes, this kind of understanding of transnationalism encompasses such a large variety of encounters that it may be difficult to keep a clear focus on the phenomenon. ${ }^{13}$ However, in this case I think a broad understanding of transnationalism is useful to highlight the different ways in which television crossed national borders in the early 1960s. Nearly every issue of Katso in 1960 featured some discussion of television in a transnational context. Transnational themes fall into four categories: (1) learning about television in other countries; (2) the Eurovision and Nordvision networks; (3) watching television across national borders; and (4) visions of world television. Whereas in the first three cases transnationalism refers to different ways of encountering television from other countries, visions of world television question national boundaries altogether. Apart from the Eurovision and Nordvision networks, all of these categories include discussion of both Eastern and Western television cultures.

\section{Learning about Television in Other Countries}

The early issues of Katso illustrate how the Finnish television culture developed in close contact with television in other countries. The magazine reported about television professionals' trips abroad (The Netherlands, Britain and the Soviet Union) and about courses for television and advertising professionals where foreign experts visited as teachers. Katso also published articles that introduced television in countries such as Britain and Norway and an article series on the international history of television, focusing on the USA, Western Europe and the Soviet Union. ${ }^{14}$

British television was an important role model for Finnish television. ${ }^{15}$ The second issue of Katso featured two articles about British television. The managing director of Tesvisio Väinö Nurmimaa told readers about his visit to London where he had acquired programmes for Tesvisio and acquainted himself with Independent Television. ${ }^{16}$ In another article the actress and director Kyllikki Forssell was interviewed about her visit to England where she had observed drama productions at the BBC. Although the BBC studios impressed her with their size, Forssell did not see British television drama as a straightforward ideal, commenting that its quality did not always satisfy 'a demanding viewer'

\footnotetext{
10 Sari Elfving, Taikalaatikko ja tunteiden tulkit: Televisio-ohjelmia ja esiintyjiä koskeva kirjoittelu suomalaisissa lehdissä 1960- ja 1970-luvuilla ('The magic box and the interpreters of emotions: Writing about television programmes and performers in the Finnish press in the 1960s and 1970s'). Tampere University Press, 2008, p. 81.

11 There was also a radio magazine Radiokuuntelija which had been published since 1936 and gradually featured television alongside radio, but Katso focused especially on television. A family magazine under the same name had been published in the late 1950s but in 1960 Katso started over as a television magazine. See Elfving 2008, p. 68.

12 Elfving 2008, p. 78.

13 See Patricia Clavin, 'Defining Transnationalism,' Contemporary European History, 14, 4, 2005, 423.

${ }^{14}$ E.g. Paavo Kärnä, 'Television historia' ('The history of television'), Katso, 3, 1960, 6-8; 'Norjan televisio' ('Norwegian television'), Katso 10, 1960, 6-7.

${ }^{15}$ See Heidi Keinonen, Kamppailu yleistelevisiosta: TES-TV:n, Mainos-TV:n ja Tesvision merkitykset suomalaisessa televisiokulttuurissa 19561964 ('The struggle over public television: The meanings of TES-TV, Mainos-TV, and Tesvisio in the Finnish television culture 1956-1964'). Tampere University Press, 2011, pp. 179-182.

16 'Tesvisio brittien luona' ('Tesvisio visits the Brits'), Katso, 2, 1960, 18.
} 
and that the BBC could afford to do better. Forssell also presented Finnish plays translated into English to the 'tv gentlemen of the BBC' in the hope that some of them might be produced for British television. ${ }^{17}$ In this account, Finnish television professionals not only learned from British television, but also hoped to influence it.

Tallinn television was also featured in the second issue of Katso. ${ }^{18}$ Like the articles on Western European television, the article on Tallinn television informed readers about the currents facilities and future plans of the station at the time. The difference is that the article was not based on an interview with a Finnish television professional, but rather the writer (whose name was not given as was common practise in Katso at the time) visited Tallinn television studios with an unidentified group of Finnish visitors. Later Katso reported about a group of STV employees visiting Leningrad, where they had among other things observed a live broadcast at the Kirov stadium. ${ }^{19}$ This short article did not feature interviews.

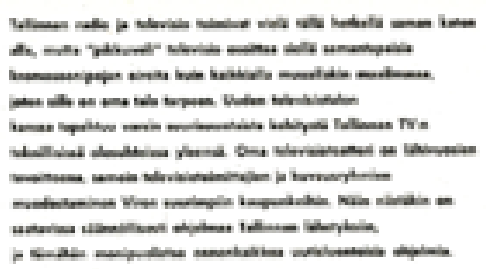

\section{a TALLINNA TELEVISIOONI STUUDIO}

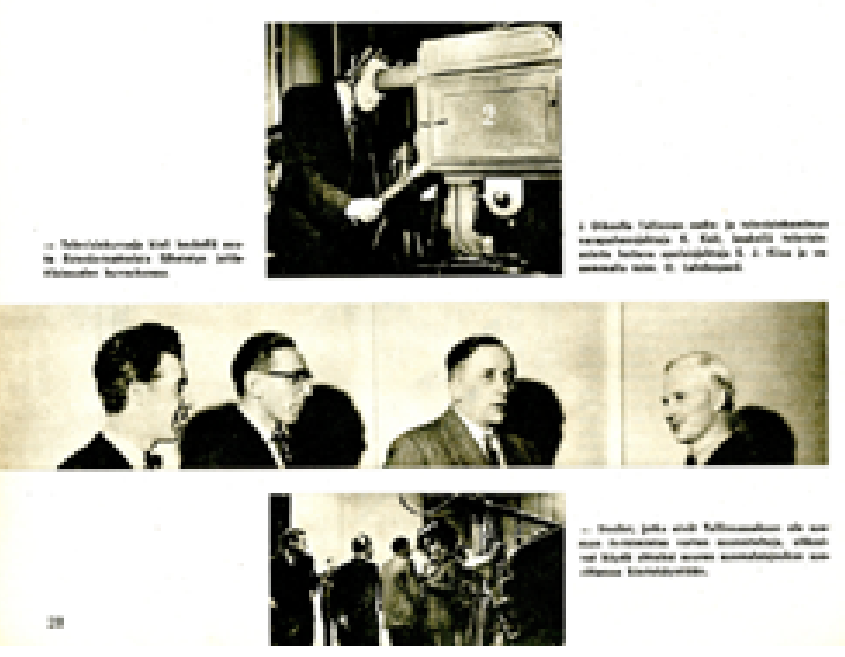

Figure 1: Finnish visitors at the television studio in Tallinn, Katso 2/1960. The caption of the bottom image comments that the studios in Tallinn, like in Helsinki, were not originally designed for television production and were crowded during the tour of the large group of Finnish visitors.

Katso introduced readers to both Western European and Soviet television, although it gave more attention to Western European television. Finnish television professionals were invited to visit television stations in both the East and the West, and Katso represented both as having something to offer Finnish television professionals and viewers. 
However, in comparison with Kyllikki Forssell's interview about British television, which included personal impressions and criticism, the article on Tallinn television had a more official tone, passing on the information given by the directors of Tallinn television. The interviews bring Western European television closer to the reader than Soviet television.

\section{The Eurovision and Nordvision Networks}

In the fall of 1960, YLE had just joined the Eurovision and Nordvision networks. Katso represented this as a milestone in the popularisation of television in Finland, writing: 'Eurovision broadcasts from [the summer Olympics in] Rome can without exaggeration be said to have caused television to make its final breakthrough in our country. ${ }^{20}$ International programme exchange networks were an important source of programming, amounting to over ten percent of STV programmes in $1960 .{ }^{21}$

Katso described the history and operations of Eurovision in an article entitled 'Eurovision: A television family of 16 countries', based on the journalist's visit to the EBU headquarters in Geneva. The family metaphor - Eurovision as a 'television family' - emphasised a sense of community and belonging enabled by television. The article interpreted the rapid growth of Eurovision as a sign that the network was 'born out of the needs and spirit of the era,' referring to the European need to come together in the rapidly changing world of the 1950s. ${ }^{22}$ This could be seen as a reference to the East/West split in Europe. However, Katso did not represent Eurovision in terms of an East/West division. According to Katso, Eurovision encompassed all 'North and West European countries' as well as Yugoslavia as a foray into Eastern Europe. ${ }^{23}$ The reference to Northern and Western Europe avoids a dichotomous view of Europe by representing Northern Europe as a third category that is not a part of either East or West.

Nordvision was not a separate organisation in the early 1960s, but a name given to the practical programme exchange among the Nordic public service broadcasters. ${ }^{24}$ Whilst the Eurovision exchange provided mainly sports, classical music and coverage of events such as royal weddings and state visits, the Nordvision programmes exchange featured even light entertainment. In 1960, Nordvision programmes on Finnish television included, for example, a light entertainment series filmed at the Tivoli in Copenhagen, a Norwegian popular music series and a programme about the Swedish troubadour Evert Taube. ${ }^{25}$ In this way, Nordvision helped to make popular entertainment from the Nordic countries familiar across national borders.

Katso did not mention Intervision in 1960. While the Intervision programme exchange had begun in February 1960 , YLE only joined the network in $1965 .{ }^{26}$ YLE did not broadcast Intervision material in 1960, but the following year the YLE annual report listed 14 Intervision programmes. ${ }^{27}$ The most notable Intervision programmes were football matches and broadcasts related to Soviet space flights. ${ }^{28}$ However, the Eurovision and Nordvision networks remained

\footnotetext{
20 ARVIO, 'Arviointia' ('Criticism'), Katso, 3, 1960, 25.

21 Of these, 9,2 \% were Eurovision programmes and 2,1 \% Nordvision programmes. Kertomus Oy. Yleisradio Ab:n toiminnasta vuonna 1960, YLE, 1961, p. 77.

22 Paula Porkka, 'Eurovisio: 16 maan tv-perhe' ('Eurovision: A television family of 16 countries'), Katso, 5, 1960, 34-35

23 Paula Porkka, 'Eurovisio: 16 maan tv-perhe,' Katso, 5, 1960, 35.

24 Raimo Arhela, 'Yhteistoimintaa yli rajojen' ('Co-operation across borders'), in Kaarle Stewen, ed., Tämä on televisio: Opas suomalaisen tv:n maailmaan ('This is television: A guide to the world of Finnish television'), Weilin+Göös, 1968, pp. $218-219$.

25 Kertomus Oy. Yleisradio Ab:n toiminnasta vuonna 1960, YLE, 1961, p. 72; 'Ruotsalainen trubaduuri' ('A Swedish troubadour'), Katso, 12, 1960, 19.

26 Ernest Eugster, Television Programming across National Boundaries: The EBU and OIRT Experience, Artech House, 1983 , pp. 105-106.

27 The YLE annual reports consider even programmes received directly from Moscow as Intervision broadcasts, although technically they did not come from the Intervision network. Kertomus Oy. Yleisradio Ab:n toiminnasta vuonna 1960, YLE, 1961; Kertomus Oy. Yleisradio Ab:n toiminnasta vuonna 1961, YLE, 1962, p. 83.

${ }^{28}$ Kertomus Oy. Yleisradio Ab:n toiminnasta vuonna 1961, YLE, 1962, p. 83. For YLE's involvement in the live broadcast of the celebration of Yuri Gagarin's space flight from Moscow to the Eurovision and Intervision networks, see Lars Lundgren, 'Live from Moscow: The Celebration of Yuri Gagarin and Transnational Television in Europe,' VIEW: Journal of European Television History and Culture, 1, 2, 2012, 45-55.
} 
the most significant sources of programme exchange in the early 1960s. ${ }^{29}$ Katso would introduce the Intervision network to its readers in 1964 in an article that emphasised Finland's role as a mediator in the television programme flow between East and West. ${ }^{30}$

\section{Watching Television across National Borders}

In the beginning of the 1960s, Finnish television channels could be viewed only in southern Finland. This allowed foreign television channels to become a source of programming in some areas.

The television schedules published by Katso indicate a television environment that was not defined by national boundaries. Katso published the programme information for two Finnish channels operated by three different companies as well as for Swedish television. The magazine wrote that they had also wanted to publish the Tallinn television schedule, but the programme information was not available early enough to allow publication. ${ }^{31}$ Katso explained that while Swedish television had already provided a second channel in the Turku area in Southwest Finland, there had recently been reports of people accessing the broadcasts further north on the west coast where Finnish television channels were unavailable. ${ }^{32}$ The new transmitter station in Vännes, set up in the fall of 1960, expanded the area where Swedish broadcasts could be seen up to Ostrobothnia. In Vaasa, for example, radio stores displayed television sets that showed Swedish broadcasts on their windows.$^{33} \mathrm{~A}$ significant part of the population on the west coast was Swedish speaking and, as such, there was an audience for Swedish TV programmes. Katso estimated that people who mainly listened to Swedish radio had been the first to acquire television sets, while Finnish speakers were more content to wait until Finnish television reached the area. ${ }^{34}$

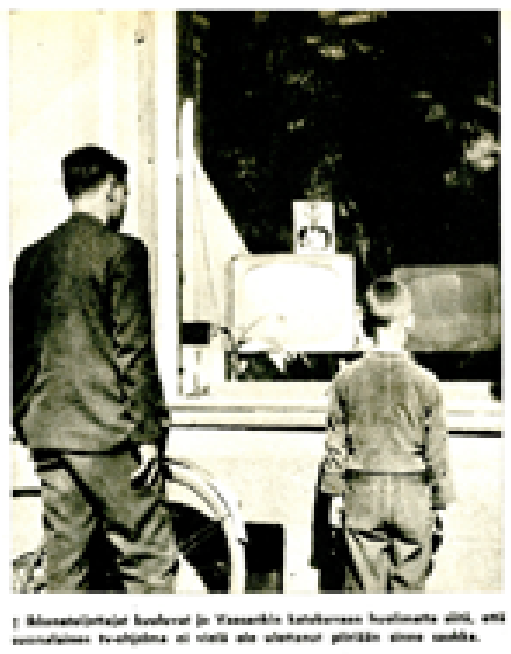

\section{ITÄÄ J A \\ L ÄNTT̈̈}

\section{Su omalaisessa} kuraruudussa

Figure 2: Illustration from the article 'East and West on a Finnish Screen,' Katso 9/1960. The caption says: 'Window gazers are already part of the street scene even in Vaasa although Finnish television broadcasts have not yet reached all the way there.'

\footnotetext{
${ }^{29}$ For example in 1961 STV broadcasted about 76 hours of Nordvision, 69 hours of Eurovision, and 29 hours of Intervision programmes, whilst the following year it broadcasted 105 hours of Eurovision, 76 hours of Nordvision and 6 hours of Intervision programmes. Kertomus Oy. Yleisradio Ab:n toiminnasta vuonna 1961, YLE, 1962, p. 83; Kertomus Oy. Yleisradio Ab:n toiminnasta vuonna 1962, YLE, 1963, p 75.

${ }^{30}$ See Mari Pajala, 'Intervision Song Contests and Finnish Television betweem East and West,' in Alec Badenoch, Andreas Fickers and Christian Henrich-Franke, eds., Airy Curtains in the European Ether: Broadcasting and the Cold War, Nomos, 2013, pp. $220-221$.

31 'Toinen numero' ('The second issue'), Katso, 2, 1960, 3.

32 'Sveriges TV' ('Sweden's TV'), Katso, 2, 1960, 32-33.

${ }_{33}$ 'Itää ja länttä suomalaisessa kuvaruudussa' ('East and West on a Finnish screen'), Katso, 9, 1960, 12.

34 'Itää ja länttä suomalaisessa kuvaruudussa,' Katso, 9, 1960, 12.
} 
Tallinn television began broadcasting in 1955 and from October 1956 it also provided programmes in Finnish. ${ }^{35}$ The attempt to address Finnish television viewers in their own language can be seen as an example of the heightened importance given to culture in the international politics of the Soviet Union after the mid-1950s. After the death of Stalin increased efforts were made to create a more positive image for the Soviet Union abroad by exporting Soviet culture, for example, through concert tours, radio and television. ${ }^{36}$ Thus, the Finnish language programming on Tallinn television was supposed to include current issues and science, children's programmes, Soviet art cinema, concerts, plays and other art productions, as well as plays by 'progressive' Finnish writers. ${ }^{37}$

According to television historians Heidi Keinonen and Raimo Salokangas, Finnish language broadcasts from Tallinn motivated the development of television broadcasting in Finland. Heidi Keinonen argues that the advent of television broadcasts from Tallinn was one of the factors that motivated radio engineers to set up the television club that went on to launch TES-TV. The first meeting of the club proposed that Finnish television should use the European television standard as opposed to the Soviet one ${ }^{38}$ YLE hesitated to expand to television broadcasting, as its resources were still needed to develop radio. The director general of the company Einar Sundström was, however, concerned by the launch of Tallinn television. He discussed these concerns with the British ambassador in Helsinki and indicated that television could provide an effective propaganda tool for the Soviet Union. ${ }^{39}$ While television professionals expressed these kinds of concerns about Soviet influence behind the scenes, Katso did not raise similar issues.

Katso represented Tallinn television as a way of expanding the available television programming. The article on Tallinn television emphasised that the new two-way link connection between Tallinn and Leningrad made it possible to watch broadcasts from Moscow in parts of Finland. Tallinn television could make major sports and political events with international importance from Moscow available for Finnish viewers..$^{40} \mathrm{~A}$ cartoon about the 'Katsola family' pictured a diverse television environment: the father is on his way home, looking forward to watching a football match between Moscow Dynamo and an Estonian team on Tallinn television. The daughter is similarly excited about a Paul Anka film on YLE's channel that evening, while the little brother plans to watch an exciting film about Indians on Tesvisio. At home they fight about which channel to watch and in the end, the mother turns off the television set, leaving everyone unhappy. ${ }^{41}$

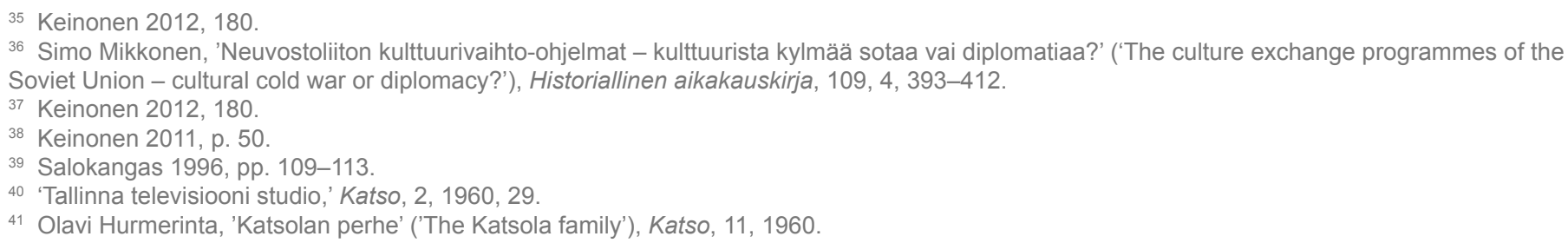




\section{KATSOLAN}
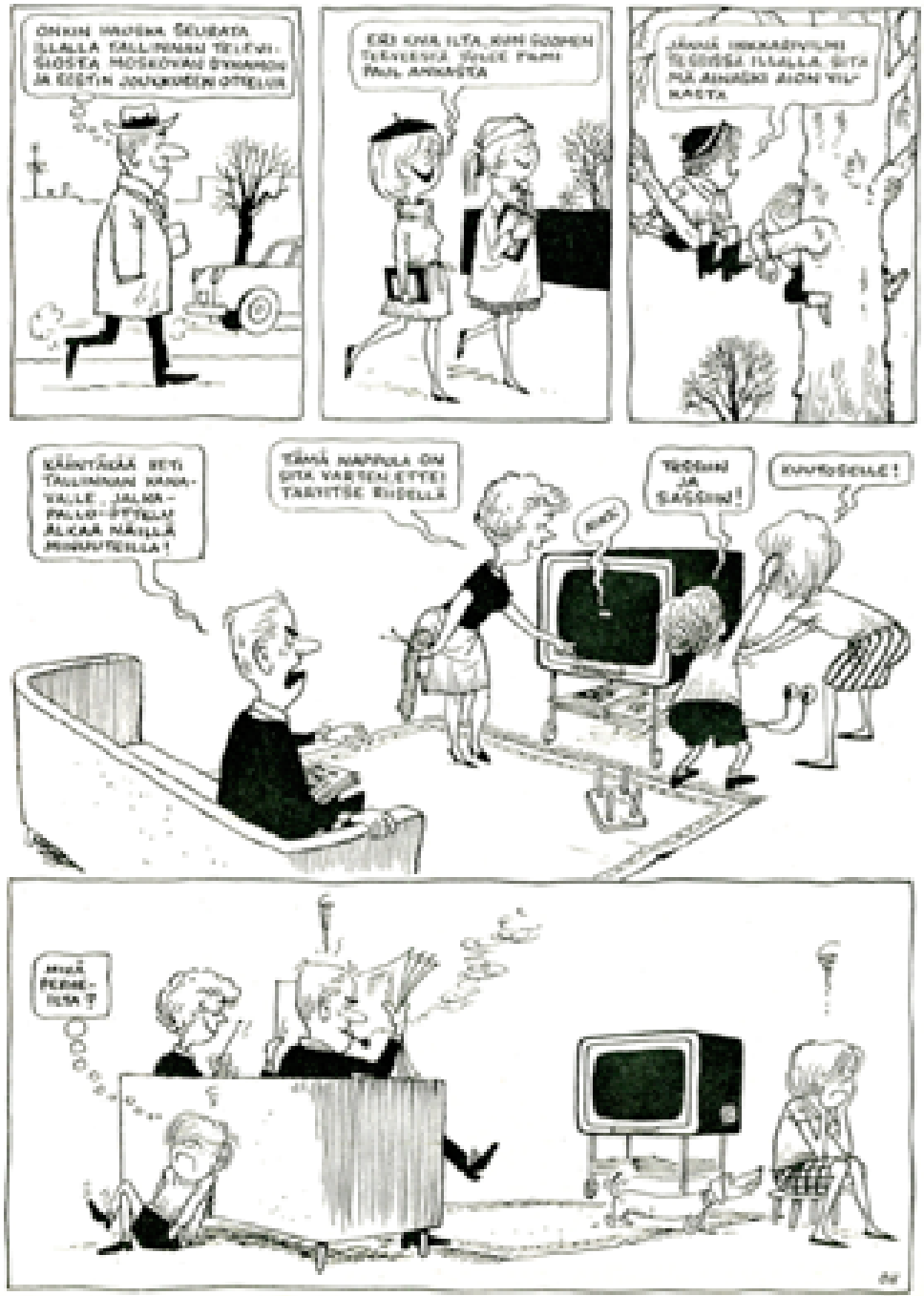

Figure 3: 'The Katsola family,' Katso 11/1960. The family argues about whether to watch football on Tallinn television, Paul Anka on STV/MTV or an adventure film on Tesvisio until the mother switches the television off to end the argument.

The cartoon's vision of the television environment differs strikingly from typical understandings of television's 'era of scarcity', characterised as a time when there were few channels and programmes to choose from and television served the construction of a national community. ${ }^{42}$ The fictional television viewers in the cartoon have access to a variety of programming from different countries. The young people are interested in American popular culture, which the cartoon associates with both Finnish television channels. However, the cartoon represents Tallinn television equally as a source of popular television. This kind of a situation could only have been reality for a small group of television owners in the Helsinki area. However, the cartoon is significant as an image of what television could be, a source of popular television from both the West and the East. 
Apart from Swedish and Tallinn television, Katso also wrote about viewers who were able to access television broadcasts from far away. These people resemble radio amateurs, although Katso does not use this term. An article about the history of television told the story of a radio employee in Oulu in Northern Finland who built the first television receiver in Finland and was able to watch television broadcasts from Germany, the Soviet Union and England in $1933 . .^{43}$ In the early 1960s context, Katso discussed foreign broadcasts as a potential way of accessing television for people who lived in areas that Finnish television channels could not reach. An article called 'East and West on a Finnish screen' featured a family in Eastern Finland who had already owned a television set for three years, even though Finnish television was not available in the area. Instead of Finnish television channels, the family had among other things, watched Eurovision broadcasts from the Rome Olympics on a German channel. Sometimes they also received broadcasts from Leningrad and Moscow; once the 'family attended a fashion show in Moscow' via television. ${ }^{44}$

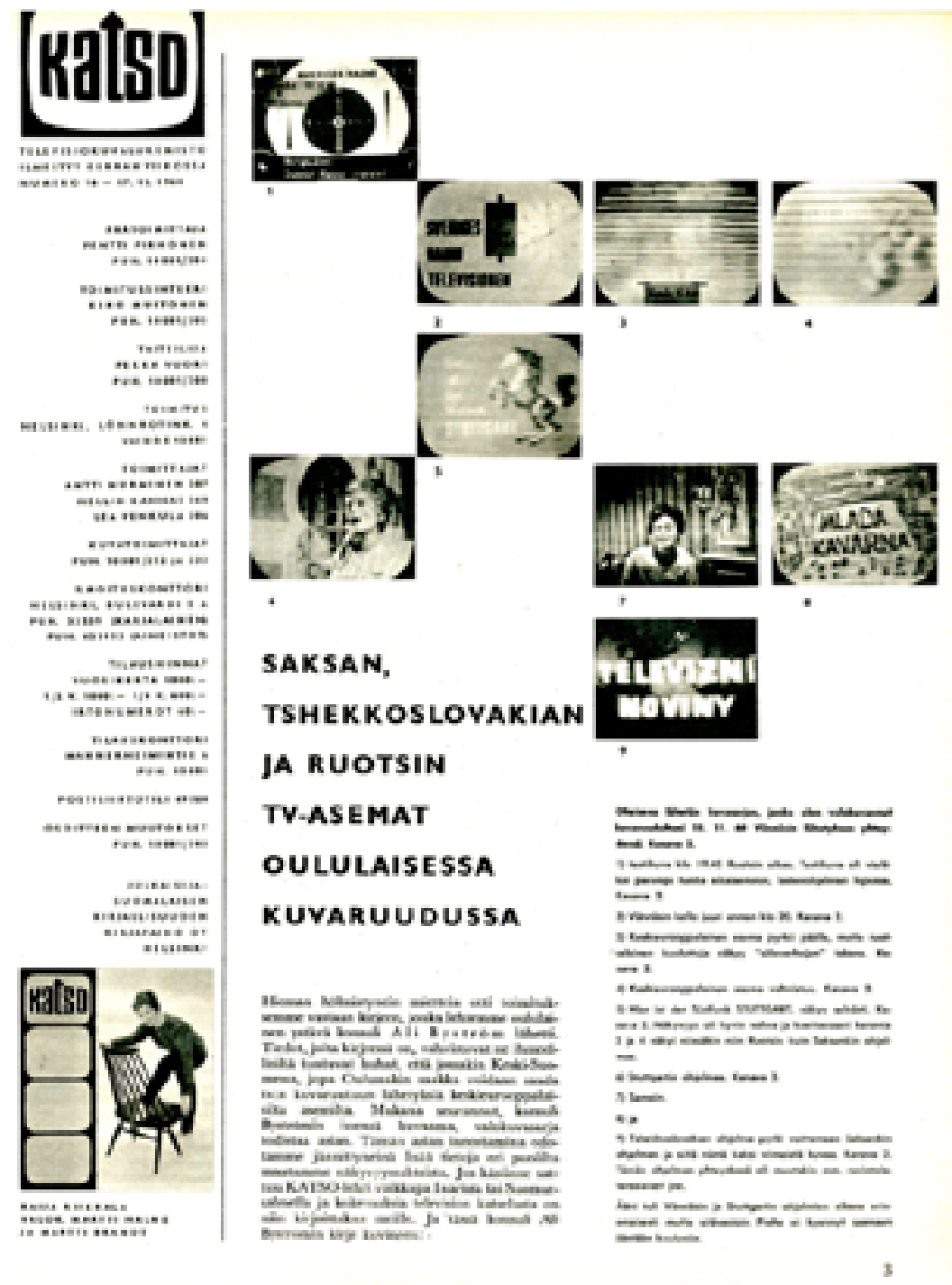

Figure 4: Images of television programmes from West Germany, Czechoslovakia and Sweden photographed by a reader in Oulu in Northern Finland, Katso 16/1960. Katso's editorial expresses amazement at the possibility of accessing broadcasts across such distance and invites more readers in Northern Finland to write in about their experiences of television.

43 Paavo Kärnä, 'Television historia,' Katso, 3, 1960, 6-8.

44 'Itää ja länttä suomalaisessa kuvaruudussa,' Katso, 9, 1960, 12 
The editorial of one issue reported about a reader who had been able to receive television broadcasts from Sweden, West Germany (Stuttgart) and Czechoslovakia (without sound) in Oulu, Northern Finland, where even Finnish television channels were not yet available. To prove this claim the reader had sent Katso images he had photographed on his television screen. The images show programmes and test cards featuring different languages. ${ }^{45}$ The photographs of the television screen present the possibility of encountering programmes from surprising and far away stations as one of the potential attractions of television. The different language texts seen in the images underline the fascination of accessing foreign programmes through television. At the same time, the images of female performers, programme graphics and test cards are also recognisable in their televisuality: these are the kinds of images you would expect to see on television. ${ }^{46}$ Televisuality is equally recognisable in both Eastern and Western European television.

Katso's reports of viewers accessing television from far away appear as curiosities, now largely forgotten. They picture television as a medium that could cross national borders and geographical distance in surprising ways, also across ideological barriers. At a time when television had not yet become a national medium in Finland, they pointed to alternative forms of understanding television.

\section{Visions of World Television}

Television's ability to overcome spatial distance was central in the visions of world television, a recurring theme in the 1960 issues of Katso. The idea of global television had shaped understandings of the possibilities of television as a medium long before television broadcasting began in Finland. Already in 1946 the film magazine Uutisaitta employed the concept of world television (koko-maailman-televisio) in an article that introduced the new medium. It suggested that world television could prevent future wars by bringing nations into such close contact with each other that no dictator could distort the truth. ${ }^{47}$ Uutisaitta's vision of world television exemplifies utopian hopes that are often attached to new media technologies. As Michael Curtin has argued, television made it possible to imagine a global community that would gather to share 'moments, emotions, and events'. ${ }^{48}$ These ideas were popularised with the international success of Marshall McLuhan's The Gutenberg Galaxy (1962), which envisioned a 'global village' enabled by televisual communication. ${ }^{49}$ While Katso participated in the early 1960 s discourse on world television, it did not repeat Uutisaitta's utopian hopes for furthering peace and understanding through television.

Katso's discussion of world television concentrated on Western, particularly US, efforts. Whilst reporting on courses for television and advertising professionals Katso referred to Mr Archibald, a London based advertising professional, who visited Finland as a teacher on these courses and advocated for world television enthusiastically. ${ }^{50} \mathrm{An}$ article entitled 'World television in sight' discussed plans for world television and technological solutions that would enable it. The article described American efforts to become the 'communication centre' of the world. In addition, it referred to British and Australian plans for world television, characterising the British plans as mainly commercially motivated. ${ }^{51}$ In the early 1960s the US government was interested in global television as a means of keeping far away regions, especially

\footnotetext{
45 'Saksan, Tshekkoslovakian ja Ruotsin tv-asemat oululaisessa kuvaruudussa' (German, Czechoslovakian, and Swedish television stations on a screen in Oulu'), Katso, 16, 1960, 3.

46 By televisuality I do not here refer to a specific American television aesthetic (see John Thornton Caldwell, Televisuality: Style, Crisis and Authority in American Television, Rutgers University Press, 1995), but more generally to historically specific ideas about kinds of forms of expression are characteristic for television as a medium.

47 Hannu Salmi, 'Intermediality in the Visions of "World Television" in the 1970s: A Cultural Historical Approach,' in Juha Herkman, Taisto Hujanen and Paavo Oinonen, eds., Intermediality and Media Change, Tampere University Press, 2012, p. 123.

48 Michael Curtin, 'Dynasty in Drag: Imagining Global TV,' in Lynn Spigel and Michael Curtin, eds., The Revolution Wasn't Televised: Sixties Television and Social Conflict, Routledge, 1997, p. 247

49 Curtin 1997, pp. 245-246.

50 CACTUS, 'Tätä ette nähneet' ('This you did not see'), Katso 3, 1960, 26; 'Mainostoimittajien tv-kurssit' ('Television courses for advertising professionals'), Katso, 11, 1960, 33.

51 'Maailmantelevisio näköpiirissä' ('World television in sight'), Katso, 5, 1960, 3-5.
} 
emerging third world nations, within its sphere of influence. The idea of global television fitted in well with the US claim of promoting the free flow of information in contrast with the communist regulation of information. ${ }^{52}$ As Michael Curtin points out, world television 'was but one more way in which the United Sates pursued geopolitical supremacy at the height of the Cold War'. ${ }^{53}$

Katso's 'World television in sight' article placed the interest in world television in a Cold War context. While the magazine referred to US efforts to become a global 'communication centre', it pointed out that that there was no information regarding similar plans from the 'Eastern bloc', although no doubt the Soviets with their knowledge of space technology would have had the requisite capacity. Katso commented that world television would be an excellent propaganda tool for totalitarian states. ${ }^{54}$ Thus, Katso did not directly discuss US efforts to create world television as ideological, but brought up the ideological uses of world television only when talking about totalitarian propaganda. The more subtle ways in which 'global televisual presence' maintains power hierarchies between geographical regions ${ }^{55}$ did not register as similarly ideological in Katso.

\section{Conclusion}

The early issues of Katso discussed television very much in a transnational context. The understanding of television that emerged in the magazine emphasised the literal meaning of television; seeing at a distance. In these early 1960s visions of television, television was not (yet) confined to the national sphere. While YLE already attempted to define television as a national medium by calling its channel Finland's Television, no television channel could at the time reach the country as a whole. Katso set no limits to what television could do in terms of overcoming physical distance - Finnish viewers could access television across surprising distances, or world television might become a reality in the near future. Ideological borders did not pose an obstacle for television broadcasts in Katso's writing. Sonja de Leeuw has shown how in the Netherlands an early discourse on television as a transnational medium was overtaken by ideological and political powers that co-opted television for serving the nation. ${ }^{56}$ Similarly the understanding of television in the first volume of Katso featured many transnational elements that were later overcome by an emphasis on television as a national medium.

Katso's vision of the Finnish television environment encompassed encounters with both Western and Socialist television cultures. While Katso discussed television in Europe, the USA and the Soviet Union, it paid more attention to television in the so-called West. For the most part, the magazine maintained an apolitical tone in discussing television in different countries or the plans for world television. The magazine's tone reflected the need to be careful in addressing international politics in the Cold War era in Finland. Katso represented Soviet television as a potential source of popular television alongside the Finnish and Swedish channels. By positing Northern Europe as a separate group it avoided having to situate Finland in relation to Eastern and Western Europe.

This article has discussed transnational features in the early 1960s Finnish television environment by analysing a specific forum that participated in its construction, the television magazine Katso. As such, the scope of the article is necessarily limited. A more complete picture of transnationality in the Finnish television environment and of the role of socialist television in it would make use of a larger variety of media and archival sources as well as memory work materials that would focus on viewers' experiences of television. A lot of research has been done in Finland on the

\footnotetext{
52 Curtin 1997, pp. 247-253.

53 Curtin 1997, p. 257.

54 'Maailmantelevisio näköpiirissä,' Katso, 5, 1960, 3-5.

55 Lisa Parks, 'As the Earth Spins: NBC's Wide Wide World and Live Global Television in the 1950s,' Screen 42, 4, $2001,349$.

56 Sonja de Leeuw, 'Transnationality in Dutch (Pre) Television: The Central Role of Erik de Vries,' Media History, 16, 1, $2010,24$.
} 
M. Pajala, 'East and West on the Finnish Screen'

political history of the Cold War era, with a focus on leading political figures and 'official' state history. ${ }^{57}$ In contrast, research on cultural encounters with socialist countries in Europe is only starting to develop. Television history has a lot of untapped potential in this regard, as television was a popular medium that introduced a variety of materials from and about socialist countries to Finnish viewers.

\section{Bi ograph y:}

Mari Pajala is Senior Lecturer in Media Studies at the University of Turku. Her research on television has focused on Finnish television history and culture, television as a technology of cultural memory, and the history of televised song contests in Europe. Her work was published in journals such as Critical Studies in Media Communication, Media History, and Critical Studies in Television.

57 E.g. Timo Vihavainen, Kansakunta rähmällään: Suomettumisen lyhyt historia ('A nation stumbles: A short history of Finlandization') , Otava, 1991; Vesa Vares, ed., Poliittista ystävyyttä: YYA-sopimus 60 vuotta: henkivakuutusta, reaalipolitiikkaa, ystävyyttä? ('Political friendship: 60 years of the agreement of friendship and cooperation: life insurance, political realism, friendship?'), Turun yliopisto, 2009. 